\title{
HUBUNGAN PENGETAHUAN GIZI IBU HAMIL DENGAN PENINGKATAN BERAT BADAN SELAMA KEHAMILAN
}

\author{
Yosi Yusrotul Khasanah \\ Sekolah Tinggi Ilmu Kesehatan (STIKes) Cirebon \\ Email: yosiyusrotulkhasanah@gmail.com
}

\section{Abstract}

Nutritional status is a measure of success in fulfilling nutrition for pregnant woman. Pregnant woman's nutrition is a nutrition that is needed in large quantities to fulfillment nutrition for pregnant woman and development of fetus which was conceived. Need for food are seen not only in portions that are eaten but must be determined on the quality of nutrients contained in the food consumed. Nutritional status on pregnant woman is one of indicator in measuring the nutritional status of the community. If the nutritional intake for pregnant women from food is not balanced with the body's needs, so will happen a nutrient deficiency (ZAKI, 2019). Determine nutritional status on pregnant woman can be done with two ways, that is by counting BMI or measuring MUAC (Mid Upper Arm Circumference). A pregnant woman is said to have normal nutritional status when have BMI more 18,5 until $24,9 \mathrm{~kg} / \mathrm{m} 2$ during pregnancy or be marked with the results of MUAC measurements more than one or is $23,5 \mathrm{~cm}$ which is an indicator of a mother not experiencing Chronic Energy Deficiency (CED). Normal nutritional status of pregnant women is expected to give birth to healthy babies and mothers can undergo safe pregnancy and childbirth (Arisman \& Kes, 2009). The result of study who be done in public health center of Mayung subdistrict Gunung Jati from 80 pregnant woman that do visit ANC from March 7 to April 9, 2019 be found as many as 15 pregnant women included in the category of malnutrition with indicators, MUAC<23,5 cm. Nutritional status is a measure of success in fulfilling nutrition for pregnant women. Pregnant woman's nutrition is a nutrient that is needed in large quantities for the fulfillment of the mother's own nutrition and the development of the fetus it contains. Food needs are seen not only in the portion eaten but must be determined on the quality of nutrients contained in the food consumed. The nutritional status of pregnant women is one indicator in measuring the nutritional status of the community. If the nutritional intake for pregnant women from food is not balanced with the body's needs, nutrient deficiency will occur (Arisman \& Kes, 2009). Increased weight of pregnant women who are less or excess can have an impact on both mother or fetus. Some of the effects if there is excess weight gain on pregnant women are babies born large so that they are at risk of experiencing difficulties during labor, in addition to excess weight in third trimester pregnancy is a danger sign of the risk of preeclampsia. While the impact that occurs in pregnant women whose weight gain is less than recommended during pregnancy is the risk of developing fetus, other than that malnutrition and anemia can be difficult during childbirth(Hani \& KusbandiyahJiarti, 2011). 
Kata kunci : Knowlede on pregnant woman's nutrition, Nutrition of pregnant woman, Enhancement Weight gain during pregnancy

\section{Abstrak}

Status gizi merupakan ukuran keberhasilan dalam pemenuhan nutrisi untuk ibu hamil.Gizi ibu hamil merupakan nutrisi yang diperlukan dalam jumlah yang banyak untuk pemenuhan gizi ibu sendiri dan perkembangan janin yang dikandungnya.Kebutuhan makanan dilihat bukan hanya dalam porsi yang dimakan tetapi harus ditentukan pada mutu zat-zat gizi yang terkandung dalam makanan yang dikonsumsi. Status gizi ibu hamil merupakan salah satu indikator dalam mengukur status gizi masyarakat. Jika asupan gizi untuk ibu hamil dari makanan tidak seimbang dengan kebutuhan tubuh maka akan terjadi defisiensi zat gizi.(ZAKI, 2019). Penentuan status gizi wanita hamil dapat dilakukan dengan dua cara, yaitu dengan menghitung IMT atau mengukur LILA (Lingkar Lengan Atas). Seorang ibu hamil dikatakan status gizinya normal apabila mempunyai IMT 18,5 $\mathrm{s} / \mathrm{d} 24,9 \mathrm{~kg} / \mathrm{m} 2$ selama kehamilan atau ditandai dengan hasil pengukuran LILA lebih dari atau sama dengan 23,5 cm yang merupakan indikator seorang ibu tidak mengalami Kekurangan Energi Kalori (KEK). Status gizi ibu hamil yang normal diharapkan akan melahirkan bayi yang sehat dan ibu bisa menjalani kehamilan dan persalinan yang aman (Arisman \& Kes, 2009). Hasil studi pendahuluan yang dilakukan di Puskesmas Mayung Kecamatan Gunung Jati dari, 80 orang ibu hamil yang melakukan kunjungan ANC dari tangal 7 maret sampai 9 april 2019 ditemukan sebanyak 15 orang ibu hamil yang termasuk dalam kategori gizi kurang dengan indikator, LILA $<23,5 \mathrm{~cm}$. Status gizi merupakan ukuran keberhasilan dalam pemenuhan nutrisi untuk ibu hamil. Gizi ibu hamil merupakan nutrisi yang diperlukan dalam jumlah yang banyak untuk pemenuhan gizi ibu sendiri dan perkembangan janin yang dikandungnya. Kebutuhan makanan dilihat bukan hanya dalam porsi yang dimakan tetapi harus ditentukan pada mutu zat-zat gizi yang terkandung dalam makanan yang dikonsumsi. Status gizi ibu hamil merupakan salah satu indikator dalam mengukur status gizi masyarakat. Jika asupan gizi untuk ibu hamil dari makanan tidak seimbang dengan kebutuhan tubuh maka akan terjadi defisiensi zat gizi (Arisman \& Kes, 2009). Peningkatan berat badan ibu hamil yang kurang maupun berlebih dapat memberikan dampak bagi ibu maupun janin.Beberapa dampak apabila terjadi kenaikan berat badan berlebih pada ibu hamil adalah bayi yang dilahirkan besar sehingga beresiko untuk mengalami kesulitan selama persalinan, selain itu berat badan berlebih pada kehamilan trimester III merupakan tanda bahaya resiko terjadinya preeklampsia. Sedangkan dampak yang terjadi pada ibu hamil yang kenaikan berat badannya kurang dari yang direkomendasikan selama kehamilan adalah resiko tidak berkembangnya janin, selain itu kurang gizi dan anemia dapat menjadi penyulit saat melahirkan (Hani \& KusbandiyahJiarti, 2011).

Kata kunci : Pengetahuan Gizi Ibu hamil, peningkatan Berat Badan selama kehamilan.

\section{Pendahuluan}

Kesehatan merupakan aspek yang penting dalam menunjang program pembangunan. Pembangunan kesehatan bertujuan untuk meningkatkan kesadaran, 
kemauan dan kemampuan hidup sehat bagi setiap orang agar terwujud derajat kesehatan masyarakat yang optimal (Evitasari, 2016).

Gizi adalah kompenen yang sangat penting selama kehamilan.Selama menjamin kesehatan ibu dan janin, gizi berperan aktif dalam pembentukan karakter dan kemampuan yang di miliki oleh janin.Tidak banyak yang kekurangan gizi menyebabkan janin menderita penyakit tertentu yang bisa disadari setelah kelahiran atau selama masa tumbuh kembang bayi.Untuk mengantisipasi hal itu, perluh dilakukan perbaikan gizi. Perbaikan gizi ibu hamil merupakan salah satu bagian dari panca karsa husada dan panca karya husada yag di sampaikan oleh WHO sebagai system kesehatan nasional (Arisman \& Kes, 2009).

Status gizi merupakan ukuran keberhasilan dalam pemenuhan nutrisi untuk ibu hamil.Gizi ibu hamil merupakan nutrisi yang diperlukan dalam jumlah yang banyak untuk pemenuhan gizi ibu sendiri dan perkembangan janin yang dikandungnya. Kebutuhan makanan dilihat bukan hanya dalam porsi yang dimakan tetapi harus ditentukan pada mutu zat-zat gizi yang terkandung dalam makanan yang dikonsumsi. Status gizi ibu hamil merupakan salah satu indikator dalam mengukur status gizi masyarakat. Jika asupan gizi untuk ibu hamil dari makanan tidak seimbang dengan kebutuhan tubuh maka akan terjadi defisiensi zat gizi (ZAKI, 2019).

Pada ibu hamil yang memiliki kebiasaan seperti vegetarian bisa mengganti sumber protein hewani dengan nabati. Sementara pada ibu hamil dengan kelainan tertentu seperti alergi pada bahan makanan,dapat mengganti sumber makanan dengan nutrisi yang sama, konsumsi susu ibu hamil juga akan sangat membatu menyeimbangkan kebutuhan gizi ibu hamil (Arisman \& Kes, 2009).

Upaya pencegahan penyakit melalui perbaikan gizi bisa dilakukan dengan cara memberikan makanan dengan gizi seimbang pada ibu hamil. Untuk menentukan kebutuhan gizi yang di perluhkan oleh ibu hamil,selain dengan 4sehat 5 sempurna.Selama masa pemeriksaan kehamilan,gejala yang tidak wajar yang menggambarkan terganggunya kondisi kehamilan dapat di definisikan oleh dokter atau bidan, apabila hal ini di sebabkan karena kekurangan gizi tertentu, maka sumber makanan yag di konsumsi harus sesuai dengan kebutuhan gizi yag di perluhkan oleh ibu hamil (Arisman \& Kes, 2009).

Salah satu indikator derajat kesehatan masyarakat adalah jumlah angka kematian ibu maternal (AKI). Angka kematian ibu dapat berguna untuk menunjukkan gambaran tingkat status gizi, kesadaran dalam berperilaku hidup sehat serta tingkat pelayanan kesehatan terutama untuk ibu hamil. Untuk mencapai salah satu target MDGs (Millenium Development Goals) yaitu meningkatkan kesehatan ibu, maka diperlukan upaya-upaya yang efektif dan efisien serta konsisten untuk ikut bersama-sama dalam mempercepat penurunan Angka Kematian Ibu atau AKI dan Bayi Baru Lahir di Indonesia (Arisman \& Kes, 2009).

Penentuan status gizi wanita hamil dapat dilakukan dengan dua cara, yaitu dengan menghitung IMT atau mengukur LILA (Lingkar Lengan Atas). Seorang ibu hamil dikatakan status gizinya normal apabila mempunyai IMT 18,5 s/d 24,9 kg/m2 selama 
kehamilan atau ditandai dengan hasil pengukuran LILA lebih dari atau sama dengan $23,5 \mathrm{~cm}$ yang merupakan indikator seorang ibu tidak mengalami Kekurangan Energi Kalori (KEK). Status gizi ibu hamil yang normal diharapkan akan melahirkan bayi yang sehat dan ibu bisa menjalani kehamilan dan persalinan yang aman (Arisman \& Kes, 2009).

\section{Metode Penelitian}

Penelitian ini dilakukan dengan menggunakan pendekatan kuantitatif dengan desain Cross Sectional variable bebas ini meliputi pengetahuan, Gizi Ibu Hamil. Dan variable terikatnya Kenaikan Berat Badan. Populasi dalam penelitian ini adalah seluruh ibu hamil yang memeriksakan Kandungannya di wilayah kerja Puskesmas Pangkalan jumlah populasi 80 responden. Pengambilan Sampel sebesar 31 responden.instrumen menggunakan kuesioner. Data dianalisis secra statistic menggunakan uji Chi Square pada tinggkat kemaknaan 5\% $(0,05)$

\section{Hasil Penelitian}

\section{A. Hasil Penelitian}

Tabel 1 hubungan pengetahuan status gizi ibu hamil berdasarkan usia

\begin{tabular}{rll}
\hline Usia & Jumlah (n) & Presentase $(\%)$ \\
\hline $35-40$ & 1 & $3,2 \%$ \\
\hline $20-23$ & 10 & $32,3 \%$ \\
\hline $25-34$ & 20 & $64,5 \%$ \\
\hline
\end{tabular}

Tabel 2 hubungan pengetahuan status gizi ibu hamil berdasarkan tingkat Pendidikan.

\begin{tabular}{lll}
\hline $\begin{array}{c}\text { Tingkat } \\
\text { pendidikan }\end{array}$ & Jumlah (n) & Presentase (\%) \\
\hline SD & 14 & $45,1 \%$ \\
\hline SMP & 7 & $22,6 \%$ \\
\hline SMA & 10 & $32,3 \%$ \\
\hline
\end{tabular}

Table 3 karakteristik responden

\begin{tabular}{lll}
\hline \multicolumn{1}{c}{$\begin{array}{c}\text { Sumber } \\
\text { Informasi }\end{array}$} & Jumlah (n) & Presentase(\%) \\
\hline Orang tua & 13 & $43,3 \%$ \\
\hline Tenaga kesehatan & 11 & $36.6 \%$ \\
\hline Media & 7 & $21,1 \%$ \\
\hline
\end{tabular}

Data yang di peroleh tentang karakteristik responden pada penelitian hubungan pengetahuan gizi iu hamil di wilayah kerja puskesmas pangkalan yaitu 
yang menjadi responden pada usia 24-35 20 orang (64,5\%) dan usia 20-23 ada 10 orang $(32,3 \%)$ dan yang paling sedikit usia $35-40$ ada 1 orang $(3,2 \%)$.

\section{B. Pembahasan}

1. Pengetahuan gizi ibu hamil tentang peningkatan berat badan selama kehamilan

Pengetahuan tentang status gizi dengan peningkatan berat badan selama kehamilan pada ibu hamil. Pengetahuan di bagi menjadi 3 yaitu pengetahuan baik (skor 75-100\%), pengetahuan cukup (skor 56-75\%), pengetahuan kurang (skor $<56 \%$ ).

Setelah dilakukan penelitian dan pengolahan data yang di peroleh data dengan hasil dari 31 ibu hamil,ibu hamil yang mempunyai pengetahuan baik 10 orang $(51,6 \%)$, dan yang kurang sebanyak 3 orang $(9,7 \%)$. Hasil penelitian dapatdi lihat dari table.

Table 4 pengetahuan ibu hamil tentang status gizi

\begin{tabular}{lll}
\hline Pengetahuan & Jumlah & Presentase \\
\hline Baik & 10 & $51,6 \%$ \\
\hline Cukup & 18 & $38,7 \%$ \\
\hline Kurang & 3 & $9,7 \%$ \\
\hline Total & 31 & $100 \%$ \\
\hline
\end{tabular}

\section{Hubungan Pengetahuan ibu hamil tentang status gizi selama kehamilan}

Untuk menganalisis hubungan antara variable bebas dan variable terikat menggunakan analisis bivariate uji yang digunakan kai kuadrat atau chisquare.

Pada analisis bivariate hubungan pengetahuan gizi ibu hamil dengan peningkatan berat badan selama kehamilan di puskesmas pangkalan di peroleh bahwa hasil dari 31 orang.

\section{a. Analisis Univariat}

Analisis univariat adalah anaisis yang dilakukan terhadap masingmasing variabel dan hasil penelitian dan dianalisis untuk mengetahui distribusi dan persentase dari tiap variabel. Kemudian hasil yang didapatkan dimasukan dalam tabel frekuensi.Analisis univariat dilakukan menggunakan rumus berikut (Notoatmodjo, 2010).

$$
P=\frac{\mathrm{X}}{\mathrm{N}} \times 100 \%
$$

Keterangan :

P: Presentase

$\mathrm{X}$ : Jumlah kejadian pada responden

$\mathrm{N}$ : Jumlah seluruh responden

\section{b. Analisis bivariat}

Analisis bivariat adalah analisis data yang dilakukan untuk mencari korelasi atau pengaruh antara 2 variabel atau lebih yang diteliti.Pada penelitian ini sebelum dilakukan analisis data, terlebih dahulu dilakukan uji normalitas data untuk mengetahui normal atau tidaknya data yang ada. 
Pengujian normalitasdilakukan dengan menggunakan analisis deskriptifyaitu dengan membandingkan nilai skewness dan kurtosis (Notoatmodjo, 2010).

Analisis ini bertujuan untuk mengetahui adanya hubungan antara variabel-variabel independent (X1-X3) dengan variabel dependen(Y1). Untuk membuktikan adanya tidaknya hubungan tersebut, dilakukan statistik dengan derajat kepercayaan 95\% ( $\alpha=0,05)$. Pada penelitian ini pengolahan data menggunakan programsoftware pengolahan data statistik, yang nantinya akan diperoleh nilai $\mathrm{p}$. Nilai $\mathrm{p}$ akan dibandingkan dengan nilai $\alpha$. Dengan ketentuan sebagai berikut:

1) Jika nilai $\mathrm{p} \leq \alpha(\mathrm{p} \leq 0,05)$, maka hipotesis (Ho) ditolak, berarti data sampel mendukung adanya perbedaan yang signifikan.

2) Jika nilai $p>\alpha(p>0,05)$, maka hipotesis (Ho) diterima, berarti sampel tidak mendukung adanya perubahan yang bermakna.

\section{Kesimpulan}

Setelah dilakukan penelitian mengenai "Hubungan pengetahuan gizi ibu hamil terhadap peningkatan berat badan selama kehamilan" maka didapatkan kesimpulan terdapat hubungan pengetahuan ibu hamil dalam memenuhi kebutuhan gizi terhadap peningkatan berat badan ibu hamil di Puskesmas pangkalan. 
Hubungan Pengetahuan Gizi Ibu Hamil dengan Peningkatan Berat Badan Selama Kehamilan

\section{BIBLIOGRAFI}

Arisman, M. B., \& Kes, M. (2009). Keracunan Makanan Buku Ajar Ilmu Gizi. EGC.

Evitasari, D. (2016). Faktor-Faktor yang Berhubungan dengan Perilaku Pemberian Makanan Pendamping ASI Bayi Usia< 6 Bulan. Syntax Literate; Jurnal Ilmiah Indonesia, 1(3), 39-49.

Hani, U., \& KusbandiyahJiarti, M. R. (2011). Asuhan kebidanan pada kehamilan fisiologis. Jakarta: Salemba Medika.

Notoatmodjo, S. (2010). Metododologi Penelitian Kesehatan.

Zaki, M. (2019). Analisis Terhadap Peraturan Pemerintah Nomor 61 Tahun 2014 Tentang Legalisasi Aborsi Akibat Kedaruratan Medis Menurut Hukum Islam. Universitas Islam Negeri Sultan Syarif Kasim Riau. 